\title{
PERLINDUNGAN HUKUM PERSAMAAN HAK ASASI PEREMPUAN DALAM MENINGKATKAN PEREKONOMIAN INDONESIA
}

\author{
Oleh: Wiwik Sri Widiarty \\ wiwik.widiarty@gmail.com \\ Universitas Kristen Indonesia, Jakarta, Indonesia
}

\begin{abstract}
The struggle of women in achieving equality and justice has been carried out long ago, whether in the economic, social, cultural, and political aspects, in fact it has not been able to raise the dignity of women to be equal to men. Various laws and regulations governing women's rights include those implied in the Convention on Elimination of All Forms Discrimination Againts Women (CEDAW), namely the rights possessed by a woman, both because she is a human being and as a woman. Even though CEDAW has been rati ed, there are still discriminatory regulations, such as the Investment Law, Marriage Law, the Law on Placement and Protection of Overseas Workers, the Citizenship Act, and other Regional Regulations. Therefore, legal protection of women's human rights is very important, for women whose rights have been violated, especially since there are many cases of female labor violence working to help improve the family economyabroad.
\end{abstract}

Keywords: legal protection; women's human rights; female labor violence .

\section{Pendahuluan}

Terjadinya krisis ekonomi global adalah dimana seluruh sektor pasar pekonomian dunia mengalami keruntuhan, dan mempengaruhi sektor lainnya. Peran perempuan di ranah public menjadi sangat penting untuk membantu menopang kebutuhan keluarganya, mendorong perempuan dalam suatu keluarga untuk bekerja membantu suami. Dalam Pasal 27 ayat (1) Undang - undang Dasar 1945, menyebutkan adanya pengakuan terhadap prinsip persamaan hukum bagi seluruh warga Negara tanpa kecuali. ${ }^{1}$ Prinsip persamaan ini menghapuskan diskriminasi, karenanya setiap warga Negara mempunyai hak yang sama di hadapan hukum dan pemerintahan tanpamemandang agama, suku, jenis kelamin, kedudukan dan golongan. Dengan adanya pengakuan persamaan hak warga Negara, yang berarti antara laki - laki dan perempuan tidak ada perbedaan. Diakuinya prinsip persamaan di hadapan hukum dan pemerintahan di dalam Undang undang Dasar 1945 menunjukkan para pendiri Negara

1 Undang - Undang Dasar Republik Indonesia 1945,dan Undang - Undang Republik Indonesia Nomor 24 Tahun 2003 Tentang Mahkamah Konstitusi, Jakarta: Penerbit Sekretaris Jendral dan Mahkamah Konstitusi RI, 2007,hlm,44.
Indonesia, sebelum mendirikan Negara, sadar betul tentang arti pentingnya perlindungan hukum terhadap hak asasi manusia.

Pada tataran Internasional maupun nasional, instrument hukum dan peraturan perundang - undangan Indonesia mengakui tentang adanya prinsip persamaan hak antara laki-laki dan perempuan, seperti yang dimuat dalam Undang - Undang Nomor 39 Tahun 1999 Tentang Hak Asasi Manusia, yang pengaturan tersebut berlaku untuk kepentingan perempuan, selain itu yang dapat dijadikan dasar perlindungan dan pengakuan atas hak - hak perempuan, Undang - undang RI Nomor 7 Tahun 1984 Tentang Ratifikasi Konvensi PBB Tentang Penghapusan segala Bentuk Diskriminasi Terhadap Wanita. ${ }^{2}$ Dengan meratifikasi Konvensi perempuan ini, maka segala bentuk diskriminasi yang didasarkan pada perbedaan jenis kelamin (laki - laki dan perempuan) telah dihapuskan. Meskipun ada beberapa perlindungan hukum terhadap perempuan, diskriminasi terhadap perempuan masih ada hingga

\footnotetext{
2 Undang - undang Republik Indonesia Nomor 7 Tahun 1984 Tentang Ratifikasi Konvensi PBB, Tentang Penghapusan Segala Bentuk Diskriminasi Terhadap Wanita
} 
sekarang ini. Salah satu jenis ranah Hak asasi manusia adalah hak - hak perempuan yang berkaitan khusus dengan Hak asasi manusia. Jenis - jenis Hak - hak perempuan yang dilindungi antara lain: ${ }^{3}$

- Perempuan dan Kemiskinan;

- Pendidikan dan Pelatihan Perempuan;

- Perempuan dan Kesehatan;

- Tindakan Kekerasan Terhadap Perempuan;

- Perempuan dan Konflik Bersenjata;

- Perempuan dan Ekonomi;

- Perempuan dalam kekuasaan dan Pengambilan keputusan;

- Mekanisme kelembagaan bagi kemajuan perempuan;

- Hak Asasi Perempuan;

- Perempuan dan Media Massa;

- Perempuan dan Lingkungan hidup;

- Anak Perempuan.

Pada tataran tersebut diatas mengakui adanya persamaan hak antara laki - laki dan perempuan, namun dalam implementasi penyelenggaraan bernegara, diskriminasi dan ketidakadilan terhadap kaum perempuan, sehingga kaum perempuan selalu tertinggal dan termarjinalkan dalam bidang politik, ekonomi,pendidikan, pekerjaan, Kesehatan, dan budaya. ${ }^{4}$ Namun adanya Diskriminasi tersebut dikarenakan budaya patriarki yang berkembang dalam masyarakat adat di Indonesia. Pada masyarakat Indonesia dengan budaya patriarki laki - laki lebih berperan dalam memegang kekuasaan, yang secara otomatis dapat membelenggu kebebasan perempuan, dan melanggar hak - hak perempuan. Mengingat diskriminasi terhadap perempuan juga melanggar asas - asas persamaan hak dan penghargaan terhadap martabat manusia, merupakan hambatan bagi partisipasi perempuan, atas dasar persamaan hak laki-laki dalam

3 Women Research Institute, Analisa Gender Dan Anggaran Berkeadilan Gender,Cetakan Pertama, Jakarta: Women Research Institute,2006,hlm,141.

4 Deklarasi Kairo Tahun 1994 , deklarasi ini ditetapkan dalam Konperensi Dunia tentang Kependudukan dan Pembangunan di Kairo, isi tersebut yang menyebutkan: " Memajukan keseta- raan, keseimbangan, dan pemberdayaan gender sebagai landasan pembangunan program kependudukan. Melibatkan partisipasi perempuan secara penuh dalam kehidupan social, politik, ekonomi, dan budaya, sipil di tingkat Internasional, regional maupun Nasional, serta memberantas semua bentuk diskriminasi berdasarkan jenis kelamin, sebagai tujuan utam komunitas Internasional". bidang politik, social, ekonomi, dan budaya. ${ }^{5}$

\section{Permasalahan}

1). Apakah perlindungan hukum persamaan hak asasi perempuan dalam meningkatkan perekonomian Indonesia telah di jamin oleh Pemerintah ?

2). Bagaimana Implementasi perlindunganhukum hak asasi perempuan dalam Peraturan perundang - Undangan di Indonesia?

\section{Tujuan Penulisan}

1). Memahami perlindungan hukum terhadap persamaan hak asasi perempuan dalam perekonomian Indonesia.

2). Mengetahui Implementasi perlindungan hukum persamaan hak asasi perempuan dalam Peraturan Perundang - Undangan di Indonesia.

\section{Perlindungan Hukum Persamaan Hak Asasi Perempuan Dalam Meningkatkan Perkono- mian Di Indonesia}

Peran serta perempuan dalam meningkatkan perekonomian keluarga menjadi sangat penting, untuk menopang kebutuhan keluarga perempuan bekerja di industry tanpa melihat perbedaan jenis kelamin lakilaki dan perempuan. Perjuangan kaum perempuan dalam mencapai kesetaraan dan keadilan yang dilakukan sejak dahulu, ternyata belum dapat mengangkat harkat dan martabat kaum perempuan untuk dapat sejajar dengan kaum laki-laki. Sekalipun kekuasaantertinggi di Indonesia perempuan pernah di pegang oleh perempuan, dan telah banyak kaum perempuan yang memegang jabatan strategis dalam pemerintahan, ketidakadilan Gender dan ketertinggalan kaum perempuan masih belum teratasi sebagaimana yang diharapkan. Kaum perempuan tetap saja termarjinalkan dan tertinggal dalam segala aspek kehidupan, perekonomian, termasuk dalam bidang hukum. Hal ini merupakan tantangan berat bagi pemerintah. Peraturan perundang - undangan yang terkait dengan perlindungan hak asasi perempuan antara lain: Undang - undang Nomor 39 Tahun 1999 Tentang Hak

5 Pusat Kajian Wanita dan Gender Universitas Indonesia,Hak Asasi Perempuan, Instrumen Hukum UntukMewujudkan Keadi- lan Gender, Jakarta: Yayasan Obor Indonesia, 2004, hlm,9. 
Asasi Manusia, Undang - undang Nomor 23 Tahun 2004 Tentang Penghapusan Kekerasan Dalam Rumah Tangga, Undang - undang Nomor 12 Tahun 2006 Tentang Kewarganegaraan, Undang - Undang Nomor 21 Tahun 2007 Tentang Tindak Pidana Perdagangan Orang, Undang - Undang Nomor Nomor 2 Tahun 2011 atas perubahan Undang - undang Nomor 2 Tahun 2008 tentang Partai Politik, Undang - undang Nomor 7 Tahun 2017 Tentang Pemilihan Umum, Selain itu masih ada peraturan perundang - undangan yang lain adalah: Inpres Nomor 9 Tahun 2000 Tentang Pengarustamaan Gender (PUG), Kepres nomor 181 Tahun 1998 Tentang Pembentukan Komisi Pembentukan Komisi Nasional Anti Kekerasan Terhadap Perempuan atau Komnas Perempuan yang dirubah menjadi Pepres Nomor 65 Tahun 2005.

Sejak Merdeka Indonesia belum mempunyai Undang - undang Hak Asasi Manusia, baru setelah reformasi 1999 Indonesia menerbitkan Undang - Undang Nomor 39 Tahun 1999 tentang HAM. Berbeda dengan Negara - Negara lain yang di awali pada tahun 1949, lewat bergabungnya beberapa Negara - Negara Eropa ke dalam Majelis Eropa (the council of Europe), pada tahun 1949 Committee of Minister (panitia menteri), dan Majelis Parlemen ( Parlemen Assembly) di London berhasil menyusun Konvensi HAM. ${ }^{6}$ Materi dasar atau pengertian dasar HAM Eropa tidak berbeda dengan ketentuan yang telah ada di dalam Deklarasi HAM PBB, dan pencetusan HAM Negara - Negara Eropa, yang bertujuan memperkuat HAM PBB sangat kuat. Sedangkan di Negara Amerika sejak tahun 1948 membentuk suatu organisasi Negara - Negara Amerika (Organisation of America States), lewat kesepakatan "Charter Bogota 1948". Dalam Deklarasi Santiago, Chili 1959 ditegaskan kembali Negara-negara Amerika akan mengaitkan/memasukkan HAM ke dalam Konstitusinya yaitu Pada tahun 1948, saat diselenggarakan Konfrensi Negara - Negara Amerika yang ke -9. ${ }^{7} \mathrm{Di}$ Indonesia Undang - Undang HAMyang diartikan,

Hak Asasi Manusia merupakan hak dasar yang secara kodrati melekat pada diri manusia, bersifat universal dan langgeng, oleh karena itu harus dilindungi, dihormati, dipertahankan, dan tidak diabaikan, dikurangi

6 Masyur Efendi, Hak Asasi Manusia Dalam Hukum Nasional Dan Internasional, Jakarta: Penerbit Ghalia Indonesia, 1994,hlm,8283.

7 Ibid. atau dirampas oleh siapapun. ${ }^{8}$

Pada Pasal 3 ayat (3) dan Pasal 1 ayat (3) Undang - Undang HAM menyebutkan, "Setiap orang berhak atas perlindungan hukum, perlindungan hak asasi manusia tanpa diskriminasi, dan tanpa membedakan suku, ras, etnik, kelompok, golongan status social, status ekonomi, jenis kelamin, bahasa, keyakinan, politik yang berakibat pengurangan, penyimpangan, atau penghapusan, pengakuan, pelaksanaan atau penggunaan hak asasi manusia dan kebebasan dasar dalam kehidupan baik individual maupun kolektif dalam bidang politik, ekonomi, hukum, social, budaya dan aspek kehidupan lainnya". ${ }^{9}$

Hak Asasi perempuan yang tersirat dalam Convention On The Elimination Of All FormsDiscrimination Againts Women (CEDAW), yaitu hak yang dimiliki oleh seorang perempuan, baik karena Ia seorang manusia maupun sebagai seorang perempuan. Cedaw merupakan konvensi yang diakui dunia sebagai Bill of Right For Women, yang menekankan pada persamaan dan keadilan antara perempuan dan laki-laki. ${ }^{10}$ Dalam hal ini Indonesia telah meratifikasi CEDAW melalui Undang-undang Nomor 7 Tahun 1984 Tentang Penghapusan Segala bentuk Diskriminasi Terhadap Wanita, dan telah diimplementasikan dalam Pasal 45 - 51 Undang - Undang HAM, menekankan pada kesetaraan dan keadilan antara perempuan dan laki- laki (equality and equity) yaitu persamaan hak dan kesempatan serta perlakuan di segala bidang dan segala kegiatan. Pasal 2 - Pasal 16 merupakan substansi pokok yang telah mengikat Pemerintah Indonesia untuk melaksanakan pasal - pasal tersebut.Meskipun pengakuan atas hak seorang perempuan terdapat dalam berbagai peraturan baik nasional maupun internasional baik secara ekspilit maupun implisit. Namun kenyatannya Kebijakan yang dilakukan oleh Pemerintah jauh dari semangat pembaharuan hukum yang terkandung dalam CEDAW. Hal ini Indonesia masih menganut budaya patriarki yang menganggap perempuan dino-

\footnotetext{
8 Undang - Undang Republik Indonesia Nomor 39 Tahun 1999 Tentang Hak Asasi Manusia,Bandung: PT. Citra Umbara , 1999,hlm,2.

9 Ibid, hlm,5.

10 Radja Toga Sihombing, Daya Ikat Perjanjian Internasional (Konvensi CEDAW) Terhadap Hukum Nasional RepublikIndonesia: Suatu Analisis Yuridis, dalam "Perempuan dan Hukum. Menuju Hukum Yang Berspektif Kesetaraan dan Keadilan”, Jakarta: Yayasan Obor Indonesia, 2008,hlm.108-109
} 
morduakan. ${ }^{11}$ Karena perempuan adalah lemah lembut , melayani, tergantung, dan emosional. Oleh karena itu menganggaptempat yang baik adalah di lingkungan rumah, sedang laki - laki adalah sebaliknya tempat yang baik adalah di lingkungan public. ${ }^{12}$ Dengan meratifikasi Konvensi wanita, maka segala bentuk diskriminasi yang didasarkan pada jenis kelamin (laki - laki - perempuan) harus dihapus, misalkan dalam dunia politik bukanlah hanya milik pria saja, melainkan perempuan harus diberi kesempatan yang sama posisinya dalam partai politik, anggota Legislatif maupun dalam pemerintahan. Dengan demikian terjadi perbedaan antara laki - laki dan perempuan, bukan dari jenis kelaminnya, tetapi dari penghargaan prestasinya, begitu pula dengan perlakuan dalam pemberian upah bagi buruh wanita, pengupahan yang diberikan oleh perusahaan dibawah upah buruh pria yang ini harus dihapus, karena tidak sesuai dengan pengaturan hak - hak perempuan hasil ratifikasi Konvensi PBB, melalui Undang -Undang nomor 7 Tahun 1984 Tentang Ratifikasi Konvensi PBB (Penghapusan segala Bentuk Diskriminasi terhadap Permpuan). Beberapa kasus kekerasan perempuanyang terjadi di Indonesia terhadap TKI perempuan, menunjukkan adanya pelanggaran hak - hak perempuan salah satu bagian dari hak asasi manusia.

Adapun isi dari Konvensi Penghapusan Segala Bentuk Diskriminasi Terhadap Perempuan yang terdiri dari 30 Pasal antara lain: Bagian 1 terdiri dari Pasal 1- Pasal 6, memuat tentang prinsip - prinsip yang dianut oleh Konvensi, dan penekanan tentang kewajiban Negara terhadap pelaksanaan Konvensi, Bagian II, terdiri dari Pasal 7 - Pasal 9,memuat tentang Hak - hak sipil dan politik perempuan, Bagian III, terdiri dari Pasal 10 - Pasal 14, memuat tentang Hak ekonomi, social, dan budaya kaum perempuan, Bagian IV, terdiri dari Pasal 15 - Pasal 16, dimuat tentang Hak - hak perempuan di dalam Keperdataan, Bagian V, terdiri dari Pasal 17 - Pasal 22, memuat Komite CIDAW, Mekanisme Pelaporan dan Pemantauan, dan Bagian VI, terdiri dari Pasal 23 - Pasal 30 memuat tentang Pemberlakuan Konvensi, Ratifikasi, Adopsi,

\footnotetext{
11Agnes Widanti, Hukum Berkeadilan Gender, Aksi Interaksi Kelompok Buruh Perempuan Dalam Perubahan Sosial, Jakarta: Kompas, 2005, hlm, 32 Ibid, hlm, $32-33$.
}

dan Reservasi Konvensi. ${ }^{13}$

\section{PELANGGARAN HAK ASASI PEREM- PUAN}

Secara hukum hak asasi perempuan di bidang ekonomi, social, budaya, sipil, dan politik yang menjadi substansi lahirnya Deklarasi Universal Hak Asasi Manusia (DUHAM) pada 10 Desember 1948, hak asasi manusia telah mendapat pengakuan dan perlindungan penuh, martabat manusia dihargai sangat tinggi, bahwa Perserikatan Bangsa - bangsa (PBB) sebagai lembaga yang melahirkan DUHAM. ${ }^{14}$ Dengan mempertegas asas mengenai tidak dapat diterimanya diskriminasi dan menyatakan bahwa semua manusia dilahirkan bebas dan sama dalam martabat, dan hak , dan bahwa tiap orang berhak atas semua hak dan kebebasan yang dimuat di dalamnya, tanpa perbedaan apapun, termasuk perbedaan berdasarkan jenis kelamin.Di Indonesia diskriminasi terhadap perempuan hingga kini masih saja terus terjadi, walaupun CEDAW telah diratifikasi, justru saat ini masih ada peraturan daerah yang diskriminatif, dan tingkat kekerasan berbasis gender seperti, perkosaan, dan perdagangan perempuan cenderung meningkat. Hal ini penegakkan hukumnya masih lemah untuk memberikan sanksi hukuman kepada pelaku.

Berbagai jenis peraturan perundang undangan di Indonesia yang diskriminatif dianggap melanggar hak asasi perempuan, seperti perda Nomor 8 Tahun 2005 tentang Pelarangan Pelacuran yang diberlakukan di Kota Tangerang, yang menyebutkan: ${ }^{15}$ " setiap orang yang sikap atau perilakunya mencurigakan sehingga menimbulkan suatu anggapan bahwa Ia/ mereka pelacur dilarang berada di jalan - jalan umum, dilapangan - lapangan, di rumah penginapan, losmen, hotel, asrama, rumah penduduk/ kontrakan, warung warung kopi, tempat hiburan, gedung tempat tontonan, di sudut - sudut jalan atau di lorong - lorong atau tempat - tempat lain di daerah". ${ }^{16}$ Perda ini banyak 13 Sri Wiyanti eddiyono, Hak Asasi Permpuan Dan Konvensi CEDAW, Materi, Konvensi CEDAW, Jakarta : Lembaga Studi dan Advokasi Masyarakat, 2007, hlm,5.

14 Sandra Kartika, Ida Rosdalina, Konvensi Tentang Penghapusan Segala Bentuk Diskriminasi Terhadap Perem- puan, Jakarta: Lembaga Studi Pers dan Pembangunan (LSPP), 1999,hlm,1

15 Peraturan Daerah Kota Tangerang Nomor 8 Tahun 2005 Tentang Pelarangan Pelacuran, Pasal 4, ayat (1). 
menuai kritik bukan hanya pada konsep, tetapi pada implementasinya. Disamping mendapat gugatan dari sebagian masyarakat tangerang.

Pada Undang - Undang Nomor 23 Tahun 2004 tentang Penghapusan Kekerasan Dalam Rumah Tangga (KDRT), yang diharapkan dapat dijadikan sebagaiperlindungan hukum terhadap perempuan dan anak, dan terbentuknya pusat pelayanan terhadap korban, baik untuk kekerasan terhadap perempuan maupun kekerasan terhadap anak, hal ini masih saja terjadi khususnya di daerah, karena masih kurangnya pemahaman apa yang dimaksud KDRT, baik dari kalangan sebagaian masyarakat maupunjajaran penegak hukum, sarana dan prasarana yang masih kurang memadai. Kasus Perempuan dengan Kekerasan dalam Rumah Tangga sebagai salah satu penyebab perceraian, baik di Pengadilan Agama maupun di Pengadilan Negeri. ${ }^{17}$ Undang - Undang Nomor 1 Tahun 1974 Tentang Perkawinan. Undang - Undang berdsarkan kajian Koalisi Perempuan ini dianggap melanggar Hak asasi perempuan, di dalam Pasal 7 ayat (1) mengatur tentang Usia Perkawinan minimal perempuan untukmenikah 16 tahun, sementara laki - laki pada usia 19 tahun. Hal ini merugikan hak perempuan, karena semakin kecil kesempatan perempuan untuk mendapatkan pendidikan yang lebih panjang. ${ }^{18}$ Kemudian pada Undang - undang Nomor 2 Tahun 2011 Perubahan Atas Undang - undang Nomor 2 Tahun 20018 tentang Perubahan Kedua Atas Undang - Undang Nomor 17 Tahun 2014 Tentang MPR, DPR, DPD, Dan DPRD. Undang - Undang ini mengakomodasi kuota $30 \%$ keterwakilan perempuan di ranah Politik Indonesia. Menurut Ani widyani Soetjipto, Tindakan Khusus Sementara (Affirmative Action), sebagai tindakan proaktif untuk menghilangkan perlakuan diskriminasi terhadap satu kelompok social yang masih terbelakang. ${ }^{19}$ Tujuan utamaAffirmative action terhadap perempuan adalah sifatnya sementara, maksudnya adalah bahwa,

17 Putusan Pengadilan Negeri Situbondo No. 362/ pid.B/2006/PN.STB, Tanggal 28 November 2006. Terdapat 5 Kasus KDRT hingga sampai ke Mahkamah Agung, bahwa dari kasus - kasus tersebut terbukti tidak satupun perbuatan terdakwa yang di vonis oleh MA berdasarkan delik pidana yang diatur dalam Undang - undang Nomor 23 Tahun 2004 tentang Penghapusan Kekerasan Dalam Rumah Tangga.

18 Koalisi Perempuan, Kekerasan Dalam Rumah Tangga, www. Koalisiperempuan .or.id,2016

19 Ani Widyani Soetjipto, Politik Perempuan Bukan Gerhana, Jakarta: Penerbit Kompas, 2005,hlm,99 ketika kelompok - kelompok yang dilindungi itu telah terintegrasi dan tidak lagi diskriminasi, kebijakan ini bisa dicabut, karena lahan persaingan dan kompetisi telah cukup adil bagi mereka untuk bersaing bebas". ${ }^{20}$ Memberdayakan perempuan dan perjuangan perempuan dalam meningkatkan representasi perempuan di Legislatif, dapat dilakukan dengan melibatkan kaum perempuan di Legislatif lebih banyak lagi.

Indonesia adalah salah satu Negara terbesar bagi korban perdagangan orang, baik bersifat domes- tic maupun lintas batas. Mayoritas korban adalah perempuan yang diperdagangkan untuk diperkerjakan sebagai buruh atau untuk eksploitasi seksual. Dalam satu decade terakhir Indonesia telah menunjukkan komitmen yang sungguh -sungguh dengan menerbitkan Undang - undang Nomor 21 Tahun 2007 Tentang Pemberantasan Tindak Pidana Perdagangan Orang (PTPPO). Pengertian Perdagangan orang (trafficking in person) dalam Pasal 1 ayat (1) Undang - Undang PTPPO adalah “Tindakan perekrutan, atau penerimaan seseorang dengan ancaman kekerasan, penggunaan kekerasan, penculikan, penyekapan, pemalsuan, penipuan, dan penyalahgunaan kekuasaan atau posisi rentan, penjeratan uang atau memberikan bayaran atau manfaatn sehingga memperoleh persetujuan dari orang yang memegang kendali atas orang lain tersebut, baik yang dilakukan di dalam Negara maupun antar Negara, untuk tujuan eksploitasi atau mengakibatkan orang tereksploitasi". ${ }^{21}$ Keberadaan Undang - undang ini merupakan bukti keseriusan Indonesia untuk mengurangi bahkan menghapuskan perdagangan orang dengan memberikan perlindungan hukum bagi korban.

Diskriminasi perempuan dalam bentuk lain adalah persoalan kewarganegaraan terhadap perempuan sering terjadi, baik di Indonesia maupun di Negara lain yaitu berkaitan dengan kewarganegaraan perempuan yang menikah dengan warga Negara asing (perkawinan campuran), terjadi di Negara Indonesia dimana perempuan harus mengikuti kewarganegaraan suami, serta perempuan tidak berhak menentukan kewarganegaraannya kepada anak yang dilahirkannya. Berdasarkan Undang - Undang Nomor 12 Tahun 2006 Tentang Ke-

\footnotetext{
$20 \quad$ Ibid, hlm, 100 - 101

21Undang - undang Republik Indonesia Nomor 21 Tahun 2007

Tentang Pemberatasan Tindak Pidana Perdagangan Orang
} 
warganegaraan menganut asas “Ius Sanguinis ", ${ }^{22}$ yang merupakan asas yang menentukan kewarganegaraan seseorang berdasarkan keturunan, bukanberdasarkan Negara tempat kelahiran. Di dalam Undang - undang ini mengatur berkewarganegaraan ganda secara terbatas bagi anak, dan kemudian ketentuan ini diperkuat dengan Peraturan Pemerintah Nomor 2 Tahun 2007 Tentang Tata Cara Memperoleh, Kehilangan, Pembatalan, dan Memperoleh Kembali Kewarganegaraan Indonesia. Undang - undang Kewarganegaraan ini memberikan hak yang sama antara laki - laki maupun perempuan untuk menentukan Kewarganegaraan anak yang dilahirkan, namun dengan adanya pengaturan ini belum cukup memberikan perlindungan bagi perempuan dalam perkawinan campuran. Hal ini disebakan dengan adanya Pasal 26 Undang - undang Nomor 12 Tahun 2006 Tentang Kewarganegaraan yang menyebutkan bahwa, "Perempuan warga Negara Indonesia yang kawin dengan laki - laki warga Negara asing kehilangan kewarganegaraan Republik Indonesia, jika menurut hukum Negara suaminya, kewarganegaraan istri mengikuti kewarganegaraan suami sebagai akibat dari perkawinan tersebut". ${ }^{23}$ Sementara anaknya sudah memperoleh Kewarganegaraan ganda. Selain itu adanya batas waktu untuk mengajukan pernyataan untuk tetap menjadi WNI merupakan penghalang bagi perempuan untuk sepenuhnya menikmati, dan mempertahankan Kewarganegaraannya mengingat kondisi yang rentan dari perempuan, terutama bagi perempuan yang berimigrasi ke Luar Negeri, menjalani perkawinan adalah bukan hal yang mudah, perbedaan latar belakang, budaya, agama, bahasa sering menjadi persoalan yang rumit yang dihadapi oleh suami dan istri pasangan perkawinan campuran.

\footnotetext{
$22 \quad$ Firdaus Amir, Kepala Atase Imigrasi Beijing Makalah yang disampaikan dalam Sosialisasi Kekonsuleran di Sanghai di depan Imigrasi WNI, tentang Manfaat Undang - Undang Nomor 12 Tahun 2006 Tentang Kewarganegaraan, Pengganti Undang Undang Nomor 62 Tahun 1958, yang secara filosofis, yuridis, dan sosiologis dianggap sudah tidak sesuai lagi dengan perkembangan masyarakat dan Ketetatanegaraan Indonesia, ber- sifat diskriminatif, kurang terakomodasi pemenuhan Hak Asasi dan persamaan antar warga Negara, serta kurang memberikan perlindungan terhadap perempuan dan anak. Dikatakan bahwa, untuk menjamin Yuridis warga dalam memberikan perlindungan
}

Kasus pidana Tenaga Kerja Wanita dari Indonesia khususnya yang di kirim ke luar negeri masih sering kali terjadi, meskipun sudah di lindungi oleh Undang - Undang Nomor 39 Tahun 2004 Tentang Penempatan dan Perlindungan Tenaga Kerja di Luar Negeri, Penempatan buruh Migran perempuan seperti diskriminasi, kekerasan, stereotyping, marginalisasi, dan beban ganda perempuan. Kebijakan - kebijakan yang ada dalam Undang - undang ini belum memberikan perlindungan terhadap Buruh Migran Perempuan seperti misalkan dalam klaim asuransi, bagi buruh migran perempuan yang mengalami masalah hukum, upah tidak dibayar, tindakan kekerasan fisik yang menyebabkan kematian, sakit, kecelakaan, dan kerugian atas tindakan pihak lain selama dalam perjalanan pulang ke daerah asal. Tidak semua Klaim asuransi dapat diselesaikan dengan cepat dan mudah, bahkan ada kasus yang tidak mendapatkan klaim asuransi sesuai dengan jenis dan pertanggungan dan kerugian yang dialaminya atau karena jangka waktu klaim sudah lewat dari yang sudah diatur. ${ }^{24}$ Beberapa kendala yang menjadi hambatan kasus klaim asuransi bagi buruh migran perempuan dirasa masih menyulitkan TKI , mengingat lemahnya posisi TKI, dan kurangnya perlindungan yang tersedia, dan syarat - syarat yang harus dipenuhi bagi TKI.

Pengambialihan hak asasi perempuan dalam bentuk lainnya seperti hilangnya sumber - sumber penghasilan perempuan dengan terbitnya Undang - undang Nomor 25 Tahun 2007 Tentang Penanaman Modal sebagai pengganti Undang - undang Nomr 1 Tahun 1967 tentang Penanaman Modal Asing. Undang - Undang Penanaman Modal ini melegalisasi eksploitasi sumber -sumber kehidupan secara besar - besaran, melegalkan penggusuran tanah sehingga perempuan kehilangan sumber pencaharian baik dari pertanian, perkebunan atau hutan yang akhirnya memiskinkan perempuan semakin tersingkir dari sumber - sumber penghidupannya, dan kehilangan akses dan control pengelolaan sumber daya alam, dan pangan. Dalam situasi tersebut, banyak perempuan terdesak dan ter- 
paksa memilih bekerja di Luar Negeri sebagai buruh migran dalam upaya bertahan hidup. Perempuan bertanggung jawab menopang kebutuhan hidup ekonomi keluarga. $^{25}$

\section{Kesimpulan dan Saran}

Indonesia sejak Reformasi tahun 1999, banyak menerbitkan Peraturan Perundang - Undangan yang terkait dengan Hak Asasi Manusia, dan diskrimi- nasi berdasarkan jenis kelamin antara laki - laki dan perempuan. Khusus perlindungan hukum terhadaphak asasi perempuan menjadi perhatian bagi pemerintah Indonesia, karena banyaknya kasus -kasus yang terjadi terhadap perempuan baik di dalam negeri maupun di Luar negeri, sehingga merugikan bagi pihak perempuan sendiri.

Meskipun ketentuan peraturan perundang - undangan sudah ada, namun masih saja dirasakan diskriminasi terhadap hak - hak perempuan, dan jaminan akan hak tersebut belum terealisasi sepenuhnya. Pengaturan Hak - hak asasi perempuan dapat ditemui dalam Undang - Undang Perkawinan, Undang - undang Kewarganegaraan, Undang - Undang Partai Politik, Undang - undang Kekerasan Dalam Rumah Tangga, Undang - Undang Tindak Pidana Perdagangan Orang, Undang - Undang tentang Penempatan Tenaga Kerja di Luar negeri, dan Undang - Undang tentang Ratifikasi Konvensi Penghapusan Segala Bentuk Diskriminasi Terhadap Perempuan yang diadopsi dari Konvensi Penghapusan segala bentuk diskriminasi terhadap perempuan ditujukan untuk melindungi dan mempromosikan hak - hak perempuan di Indonesia. Berbagai bentuk Peraturan perundang -undangan di Indonesia mengatur hak - hak asasi perempuan yang tidak membedakan antara laki - laki dan perempuan, namun dalam pelaksanaannya berbeda perlakuan tersebut dengan jelas terjadi. Hendaknya dalam melaksanakan HAM, perlakuan hak - hak perempuan sama halnyaere dengan hak asasi laki - laki, karena kaum perempuan dapat mengakses hak - hak asasinya

25 Undang - Undang Republik Indonesia Nomor 25 Tahun 2007 Tentang Penanaman Modal dalam memajukan ekonomi keluarga maupun Negara, dan sekaligus dapat mengontrol jalannya pembangunan perekonomian di Indonesia.

\section{DAFTAR PUSTAKA}

\section{Buku Bacaan :}

Ani Widyani Soetjipto, Politik Perempuan Bukan Gerhana, Jakarta: Penerbit Kompas, 2005.

Agnes Widanti, Hukum Berkeadilan Gender, Aksi Interaksi Kelompok Buruh Perempuan

Dalam Perubahan Sosial, Jakrta: Kompas, 2005.

Masyur Efendi, Hak Asasi Manusia Dalam hukum Nasional Dan Internasional, Jakrta: Penerbit Ghalia Indonesia, 1994

Pusat Kajian Wanita Universitas Indonesia, Hak Asasi Permpuan, Instrumen Hukum Untuk Mewujudkan Keadilan Gender, Jakarta: Yayasan Obor Indonesia, 2004

Radja Toga Sihombing, Daya Ikat Perjanjian Internasional Konvensi CEDAW Terhadap Hukum

Nasional, Suatu Analisa Yuridis, Dalam "Perempuan Dan Hukum: Menuju Hukum Yang

Berspektif Kesetaraan Dan Keadilan”, Jakarta :

Yayasan Obor Indonesia, 2008

Sri Wiyanti Eddiyono, Hak asasi Perempuan Dan Konvensi CEDAW, Materi, Konvensi

$C E D A W$, Jakarta: Lembaga Studi Dan Advokasi Masyarakat, 2007

Sandra Kartika, Ida Rosdalina, Konvensi Tentang Penghapusan Segala Bentuk Diskriminasi

Terhadap Perempuan, Jakarta: Lembaga Studi

Pers Dan Pembangunan, 1999.

Women Research Institute, Analisa Gender Dan Anggaran Berkeadilan Gender, Cetakan

Pertama, Jakarta: Women Research Institute, 2006 


\title{
PERATURAN PERUNDANG -
}

UNDAN- GAN

\author{
Undang - Undang Dasar Republik \\ Indonesia 1945 \\ Undang - Undang Republik \\ Indonesia Nomor 39 Tahun 1999 \\ Tentang Hak Asasi Manusia Undang \\ - Undang Republik Indonesia Nomor
}

21

Tahun 2007 Tentang Pemberantasan Tindak

Pidana Perdagangan Orang

Undang - Undang Republik Indonesia

Nomor 12 Tahun 2006 Tentang

Kewarganegaraan

Undang - Undang Nomor 39 Tahun

2004 Tentang Penempatan Tenaga

Kerja Di Luar Negeri Undang -

Undang Nomor 25 Tahun 2007

Tentang

Penanaman Modal

Undang - Undang republic

Indonesia Nomor 7 Tahun 1984

Tentang Penghapusan Segala

Bentuk

Diskriminasi Wanita

Peraturan Daerah Kota Tangerang

Nomor 8 Tahun 2005 Tentang

Pelarangan Pelacuran 